\title{
Визначення оптимальної тривалості проведення неоад'ювантної таргетної терапіі хворим з локалізованим нирково-клітинним раком
}

\author{
О. А. Войленко, М. В. Пікуль, О. Е. Стаховський, О. А. Кононенко, С. Л. Семко,
}

Ю. В. Вітрук, Е. О. Стаховський

Національний інститут раку МОЗ України, м. Київ

\section{Determination of optimal term of conduction of neoadjuvant targeted therapy in patients with localized reno-cellular carcinoma}

\author{
O. A. Voylenko, M. V. Pikul, O. E. Stakhovskiy, O. A. Kononenko, S. L. Semko, \\ Yu. V. Vitruk, E. O. Stakhovskiy \\ National Cancer Institute, Kyiv
}

\begin{abstract}
Реферат
Мета. Визначити оптимальну тривалість проведення неоад’ювантної таргетної терапії (ТТ) в лікуванні хворих з локалізованим нирково-клітинним раком (НКР).

Матеріали і методи. До рандомізованого проспективного дослідження включено 24 пацієнти з локалізованим світлоклітинним НКР (T1a-2bNOM0), яких розподілено на дві групи: 1-ша група - 12 пацієнтів, яким проведено два блоки неоад’ювантної ТТ (пазопаніб 800 мг щоденно перорально протягом 28 днів); 2-га група - 12 пацієнтів, яким проведено чотири блоки неоад’ювантної ТТ.

Результати. Стабілізацію (шкала RECIST 1.1) констатували у 9 (75\%) пацієнтів 1-ї групи та у 8 (67\%) - 2-ї групи, часткову відповідь - у 3 (25\%) та 4 (33\%) пацієнтів відповідно $\left(\chi^{2}=0,2 ; \mathrm{p}=0,65\right)$. Медіани показника регресії пухлини в $1-и ̆$ та 2 -й групах були порівнянні: 18 [2; 27] і 17 [2; 34]\% відповідно. Значущої різниці між частотою побічних проявів за шкалою СТС АЕ ступенів 1 - 4, виконання нефректомії, інтра- та післяопераційних ускладнень та тривалістю госпіталізації в порівнюваних групах не виявлено (p >0,05).

Висновки. Оптимальною тривалістю проведення неоад’ювантної ТТ хворим з локалізованим НКР є використання двох блоків. Більша тривалість неоад’ювантної ТТ призводить до збільшення вартості лікування без подальшої регресії НКР, що не впливає на вибір тактики хірургічного втручання.

Ключові слова: нирково-клітинний рак; неоад’ювантна таргетна терапія.

Abstract

Objective. To determine an optimal term of the neoadjuvant targeted therapy (NATTH) conduction in treatment of patients, suffering localized reno-cellular carcinoma (LRCC)

Materials and methods. Into the randomized prospective investigation 24 patients, suffering clear-celled LRCC (T1a2bNOM0), who were divided into two Groups, were included: the 1-st Group - 12 patients, to whom two blocks of NATTH (peroral pazopanib $800 \mathrm{mg}$ daily during 28 days) were conducted; and the 2 -nd Group - 12 patients, to whom four blocks of NATTH were conducted.

Results. Stabilization of the process (in accordance to RECIST 1.1 scale) was registered in 9 (75\%) patients of the 1 -st Group and in $8(67 \%)$ - of the $2-$ nd Group, while a partial answer - in $3(25 \%)$ and $4(33 \%)$ patients, accordingly $\left(\chi^{2}=0.2 ; \mathrm{p}=0.65\right)$ The medians of tumoral regression in the $1-$ st and 2 -nd Groups were comparable: 18 [2; 27] and 17 [2; 34]\%, accordingly. Statistical difference between the adverse effects rate in accordance to the CTC AE scale Degrees $1-4$, performance of nephrectomy, intra- and postoperative complications and duration of the hospital stay in the Groups compared was absent ( $\mathrm{p}>0.05$ ) Conclusion. An optimal term for the NATTH conduction in patients, suffering LRCC, is application of two blocks. More durable NATTH leads to enhancement of cost of the treatment without further regress of LRCC, what do not impact the choice of the surgical treatment tactics.

Keywords: reno-cellular carcinoma; neoadjuvant targeted therapy.
\end{abstract}

Використання ТТ у хворих з локалізованим та місцеворозповсюдженим НКР у контексті підвищення вірогідності виконання органозберігаючих оперативних втручань набує дедалі більшої актуальності [1 - 4]. Незважаючи на те що хірургічне видалення пухлини залишається найбільш ефективним методом лікування у разі, коли пухлина розміщена у воротах нирки або має великий розмір (більше 4 см), у клінічній практиці частіше застосовують радикальну нефректомію, після якої значно погіршується показник ви- живаності хворих через хронічну ниркову недостатність та значно знижується якість їх життя [5 - 7]. Зменшення об’єму пухлинного процесу має за мету покращення функціональних результатів лікування та збереження частини функціонуючої паренхіми нирки [8]. Те саме стосується і хворих з локалізованим НКР, які мають імперативні показання до виконання органозберігаючого втручання.

Розширення застосування ТТ в онкоурології потребує більш детального підходу до визначення строків та три- 
валості ії застосування. Основною властивістю інгібіторів тирозинкіназ є інгібування ангіогенезу, що прямо впливає на перебіг процесів репарації в організмі [9]. 3 огляду на цей факт, вкрай важливим $є$ чітке розуміння тривалості проведення неоад'ювантного лікування з метою мінімізації ризику розвитку періопераційних ускладнень. Так, відсоткова пропорція кількості ускладнень збільшується зі збільшенням тривалості прийому препарату [10]

Мета дослідження: визначення оптимальної тривалості проведення неоад'ювантної ТТ в лікуванні хворих з локалізованим НКР.

\section{Матеріали і методи дослідження}

Для визначення оптимальної кількості циклів ТТ до проведення оперативного лікування та безпечності 14-денної відміни препарату напередодні втручання було заплановане проспективне рандомізоване дослідження щодо невеликої вибірки пацієнтів з локалізованими формами світлоклітинного НКР (Т1a-2bNOM0), яких розподілили на дві групи у співвідношенні 1:1 в залежності від кількості проведених циклів неоад'ювантного прийому пазопанібу в стандартному дозуванні (пазопаніб 800 мг щоденно перорально протягом 28 днів). До 1-ї групи включили пацієнтів, яким було проведено загалом два цикли ТТ; до 2-ї - пацієнтів яким було проведено загалом чотири 4 цикли. Діагноз верифікували шляхом перкутанної біопсії утворення нирки під контролем ультразвукового дослідження. Первинними кінцевими точками аналізу були: показник регресії пухлини під дією ТТ, відповідь пухлини за шкалою RECIST 1.1, загальна кількість ускладнень, асоційованих з прийомом препарату, у обох групах за СТС AE та кількість ускладнень 3, 4 ступеня, що потребували зниження дози препарату або його відміни.

Враховуючи літературні дані та швидкість нормалізації ангіогенезу, всім пацієнтам відміняли прийом препарату не раніше ніж за 14 днів до запланованого оперативного втручання, що було направлено на мінімізацію періопераційних ускладнень.

Вторинними кінцевими точками аналізу були: об'єм інтраопераційної крововтрати, тривалість оперативного втручання, частота післяопераційних ускладнень за класифікацією Clavien-Dindo.

Дизайн дослідження передбачав обов'язкові три контрольні візити: перший - до проведення ТТ; другий - останній день прийому таргетного препарату; третій - день виписки пацієнта. Лабораторні обстеження проводили кожні два тижні після початку ТТ до моменту відміни препарату, перед та після оперативного втручання; дані вивчали з метою додаткового аналізу ускладнень на фоні прийому ТТ. Корегували дозу та лікували побічні прояви у спосіб телефонної консультації дільничного уролога або сімейного лікаря з лікарем-дослідником. Остаточним ви-

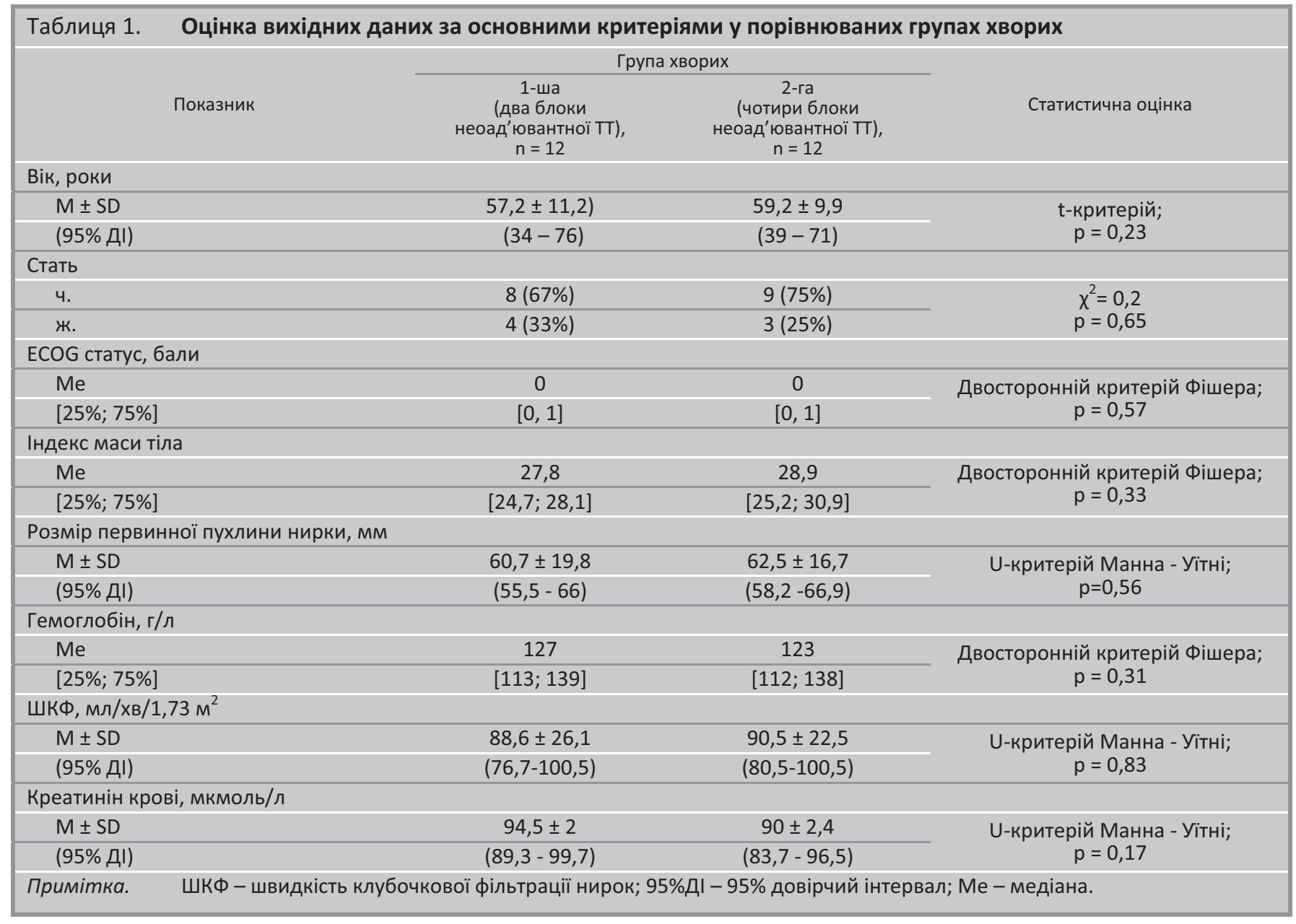


буванням з дослідження вважали виписку хворого зі стаціонару після хірургічного лікування.

Отримані результати опрацьовували за допомогою програмного забезпечення Excel 2003, STATISTICA 8.0 та SPSS. Розподіл неперервних даних у групі оцінювали шляхом побудови діаграм розподілу, а також за критері$є м$ Колмогорова-Смирнова. Описова статистика полягала в обчисленні середньої величини зі стандартним відхиленням. Кількісні показники у групах порівнювали з використанням U-критерію Манна - Уітні, якісні - $з$ використанням двостороннього критерію Фішера та критерію Пірсона для абсолютних величин. Статистично значущими вважали відмінності, коли вірогідність помилки $1-$ го роду була менше 5\% ( $<<0,05)$.

Загалом до дослідження було включено 24 пацієнти 3 гістологічно верифікованим НКР світлоклітинного типу. За основними демографічними та клінічними характеристиками (табл. 1) обидві групи пацієнтів були порівнянні (p > 0,05).

\section{Результати}

Проаналізувавши об'єктивну відповідь пухлини за шкалою RECIST 1.1 на проведену неоад’ювантну TТ за результатами комп'ютерної томографії з болюсним контрастним підсиленням та побічні прояви ТТ, ми не отримали статистично значущих відхилень в обох групах $\left(\chi^{2}=0,2 ; \mathrm{p}\right.$ $=0,65)$. Повної відповіді на ТТ та прогресії захворювання не було констатовано ужодного пацієнта. Часткову відповідь спостерігали у 3 (25\%) пацієнтів 1-ї групи та у 4 (33\%) пацієнтів 2-ї групи. Найчастіше відповідь пухлини оцінювали як стабілізацію процесу: 9 (75\%) хворих 1-ї групи, які отримали два блоки ТТ, та 8 (67\%) хворих 2-ї групі, які отримали чотири блоки ТТ. Медіани [25\%; 75\%] показника і регресії пухлини в обох групах були порівнянними та становили 18 [2; 27] і 17 [2; 34]\% відповідно. Статистично значущої різниці між частотою побічних проявів за шка- лоют СТС АЕ ступенів 1 - 4 у порівнюваних групах не виявили $\left(\chi^{2}=0,69 ; \mathrm{p}=0,4\right): 4$ (33\%) хворих 1-ї групи, які отримали два блоки ТТ, та 6 (50\%) хворих 2-ї групи, які отримали чотири блоки ТТ. Побічних проявів за шкалою СТС АЕ ступенів 3 - 4 у хворих 1-ї групи не спостерігали. У 2-й групі такі прояви зафіксували у 1 (8\%) хворого.

Після проведення неоад'ювантної ТТ всім хворим з локалізованим НКР виконано оперативне втручання.

Аналіз періопераційних міжгрупових показників ( $m a-$ бл. 2) частоти виконання органовиносного оперативного втручання, об'єму інтраопераційної крововтрати, частоти хірургічних ускладнень за класифікацією Clavien Dindo та тривалості госпіталізації після проведення оперативного лікування не показав статистично достовірної різниці між ними ( $\mathrm{p}>0,05)$.

\section{Обговорення}

У клінічній літературі немає чітких даних щодо кількості циклів неоад'ювантної терапії, а строки, про які повідомляють автори, зазвичай грунтуються на їх власному досвіді. Ці дослідники проводили в середньому від двох до шести курсів ТТ, тоді як хірургічне втручання виконували лише пацієнтам, у яких було отримано високі показники регресії захворювання [11]. Важливим фактором, котрий необхідно враховувати, $€$ наявність пацієнтів, у яких пухлини не відреагують на призначене лікування та можуть прогресувати протягом вказаного періоду [12]. 3 огляду на зазначене, можливо припустити, що, визначаючи термін, на який слід призначити ТТ в неоад'ювантному режимі, необхідно мати перед собою такі цілі: обрати мінімальний період, за який буде отримано максимальний ефект; Знизити вірогідність виникнення асоційованих $з$ прийомом препарату ускладнень; відібрати пацієнтів, у яких пухлини не відреагують на таргетний препарат до моменту настання прогресії захворювання.

\begin{tabular}{|c|c|c|c|}
\hline \multirow[b]{2}{*}{ Показник } & \multicolumn{2}{|c|}{ Група хворих } & \multirow[b]{2}{*}{ Статистична оцінка } \\
\hline & $\begin{array}{c}\text { 1-ша } \\
\text { (два блоки } \\
\text { неоад'ювантної ТT), } \\
n=12\end{array}$ & $\begin{array}{c}2-г а \\
\text { (чотири блоки } \\
\text { неоад'ювантної ТТ), } \\
\mathrm{n}=12\end{array}$ & \\
\hline \multicolumn{4}{|l|}{ Втручання } \\
\hline резекція нирки & $9(75 \%)$ & $10(83 \%)$ & $x^{2}=0,25$ \\
\hline нефректомія & $3(25 \%)$ & $2(17 \%)$ & $p=0,62$ \\
\hline \multicolumn{4}{|c|}{ Об'єм інтраоперційної крововтрати, мл } \\
\hline Me & 312 & 296 & \multirow{2}{*}{$\begin{array}{c}\text { Двосторонній критерій Фішера; } \\
\text { p }=0,47\end{array}$} \\
\hline$[25 \% ; 75 \%]$ & [90 - 640] & {$[120-700]$} & \\
\hline \multicolumn{4}{|l|}{ Тривалість операції, хв } \\
\hline $\mathrm{Me}$ & 126 & 116 & \multirow{2}{*}{$\begin{array}{c}\text { Двосторонній критерій Фішера; } \\
p=0,23\end{array}$} \\
\hline$[25 \% ; 75 \%]$ & [78 - 181] & [84 - 157] & \\
\hline \multicolumn{4}{|c|}{ Тривалість госпіталізації, ліжко-день } \\
\hline Me & 6 & 7,5 & \multirow{2}{*}{$\begin{array}{c}\text { Двосторонній критерій Фішера; } \\
\text { p =0,51 }\end{array}$} \\
\hline$[25 \% ; 75 \%]$ & {$[3-8]$} & [4 - 8] & \\
\hline \multicolumn{4}{|c|}{$\begin{array}{l}\text { Ускладнення за класифікацією } \\
\text { Clavien - Dindo }\end{array}$} \\
\hline I ступінь & $2(17 \%)$ & $1(8 \%)$ & \multirow{3}{*}{$\begin{array}{c}\chi^{2}=0,2 \\
p=0,65\end{array}$} \\
\hline ІІ ступінь & $2(17 \%)$ & $2(17 \%)$ & \\
\hline III-V ступінь & 0 & 0 & \\
\hline
\end{tabular}


Що стосується необхідного періоду відміни препарату напередодні хірургічного втручання, то він також залишається остаточно не визначеним. Переважна більшість дослідників рекомендує відміну препарату за 14 днів до запланованого хірургічного втручання, враховуючи строки виведення препарату та відновлення ангіогенезу [2 4]. В середньому періопераційні ускладнення, за даними різних досліджень, виникають у 13 - 20\% пацієнтів [13]. Проведення оперативного лікування в коротші строки зазвичай асоціюється з вищим ризиком розвитку післяопераційних ускладнень, найбільш значущим з яких є погіршення загоєння глибоких ран [2]. Проте дослідженням, проведеним T. Powles і співавторами, показано, що одноденний період відміни препарату статистично не відрізнявся від 14-денного за кількостю інтра- та післяопераційних ускладнень [13]. Про періопераційні ускладнення також не повідомили у дослідженні E. Jonasch і співавтори, хірургічна складність більше впливала на перебіг раннього післяопераційного періоду періоду (ускладнення виникали у 2 із 50 хворих), ніж власне сам прийом препарату [14]. Враховуючи наведені дані, вкрай важливо визначити оптимальний період відміни препарату напередодні хірургічного втручання.

Отримані в нашому дослідженні дані засвідчили відсутність клінічно значущої різниці між ефективністю двох і чотирьох циклів ТТ в неоад'ювантному режимі як за середнім показником регресії первинної пухлини, так і за оцінкою об'єктивної відповіді за шкалою RECIST 1.1 між групами, що вказує на доцільність проведення двох циклів неоад’ювантної ТТ. Збільшення кількості циклів до чотирьох збільшуе тривалість та вартість лікування, незначно підвищує частоту побічних проявів ТТ (з 33 до 50\%) за відсутності подальшої регресії НКР, що не впливає на вибір типу хірургічного втручання, об'єм інтраопераційної крововтрати, тривалість операції та строки госпіталізації. Вибір на користь чотирьох циклів можливий лише у обраних пацієнтів з високим показником первинної регресії з метою зменшення рівня хірургічної складності та підвищення вірогідності органозберігаючого лікування. У таких хворих продовження лікування не призведе до збільшення кількості періопераційних ускладнень. Відміна таргетного препарату за 14 днів до оперативного втручання забезпечує повне його виведення з організму, адекватні процеси репарації тканин та не спричиняє небажаних післяопераційних ускладнень.

\section{Висновки}

1. Оптимальна тривалість проведення неоад’ювантної ТТ хворим з локалізованим НКР - використання двох циклів. Збілышення кількості циклів ТТ призводить до збільшення тривалості та вартості лікування, підвищення кількості побічних проявів ТТ на 17 \% за відсутності подальшої регресії НКР, що не впливає на вибір типу хірургічного втручання, об'єм інтраопераційної крововтрати, тривалість операції та строки госпіталізації (р > 0,05).

2. Використання чотирьох циклів доцільне у обраних пацієнтів, коли отримано високий первинний показник регресії, з метою зменшення хірургічної складності пухлини та підвищення вірогідності органозберігаючого лікування.

\section{Підтвердження}

\section{Інформація про фінансування.}

Це дослідження фінансувалося в межах НДР «Визначити шляхи зменшення інвалідизації хворих з локалізованим раком нирки на основі розробки та оптимізації інноваційних методів діагностики, неоад'ювантної таргетної терапії та хірургічного лікування» (№ держреєстрації 0118U003727).

\section{Розкриття потенційного конфлікту інтересів.}

Войленко О. А. отримував гонорари доповідача від компанії Pfizer, Roche та Novartis.

\section{Інформація про внесок кожного учасника,}

Войленко О. А. - аналіз отриманих даних, написання тексту; Пікуль М. В. - аналіз отриманих даних, написання тексту; Стаховський О. Е. - збирання та опрацювання матеріалів; Кононенко О. А. - збирання та опрацювання матеріалів; Семко С. Л. - збирання та опрацювання матеріалів; Вітрук Ю. В. - збирання та опрацювання матеріалів; Стаховський Е. О. - концепція і дизайн дослідження, аналіз отриманих даних.

Всі автори прочитали та схвалили остаточний варіант рукопису.

\section{Згода на публікацію}

Всі автори дали згоду на публікацію цього рукопису.

\section{References}

1. Powles T, Kayani I, Blank C, Chowdhury S, Horenblas S, Peters J, et al. The safety and efficacy of sunitinib before planned nephrectomy in metastatic clear cell renal cancer. Ann Oncol. 2011 May;22(5):104147. doi: 10.1093/annonc/mdq564. Epub 2011 Jan 17.

2. Silberstein JL, Millard F, Mehrazin R, Kopp R, Bazzi W, DiBlasio CJ, et al. Feasibility and efficacy of neoadjuvant sunitinib before nephronsparing surgery. BJU Int 2010 Nov;106(9):1270-6. doi: 10.1111/j.1464410X.2010.09357.x.

3. Rini BI, Plimack ER, Takagi T, Elson P, Wood LS, Dreicer R, et al. A phase II study of pazopanib in patients with localized renal cell carcinoma to optimize preservation of renal parenchyma. J Urol. 2015Aug;194(2):297-303. doi: 10.1016/j.juro.2015.03.096.

4. Lane BR, Derweesh IH, Kim HL, O'Malley R, Klink J, Ercole CE, et al. Presurgical sunitinib reduces tumor size and may facilitate partial nephrectomy in patients with renal cell carcinoma. Urol Oncol. 2015 Mar;33(3):112.e15-21. doi: 10.1016/j.urolonc.2014.11.009.

5. Smith DH, Thorp ML, Gurwitz JH, McManus DD, Goldberg RJ, Allen LA, et al. Chronic Kidney Disease and Outcomes in Heart Failure With Preserved Versus Reduced Ejection Fraction. Circ Cardiovasc Qual Outcomes. 2013 May 1;6(3):333-42. doi: 10.1161/CIRCOUTCOMES.113.000221. Epub 2013 May 17.

6. Go AS, Chertow GM, Fan D, McCulloch CE, Hsu CY. Chronic kidney disease and the risks of death, cardiovascular events, and hospitalization. N Engl J Med. 2004 Sep 23;351(13):1296-305. doi: 10.1056/NEJMoa041031.

7. Huang WC, Levey AS, Serio AM, Snyder M, Vickers AJ, Raj GV, et al. Chronic kidney disease after nephrectomy in patients with renal cortical tumours: a retrospective cohort study. Lancet Oncol. 2006 Sep;7(9):73540. doi: 10.1016/S1470-2045(06)70803-8.

8. Stakhovskiy EO, Voylenko OA, Vitruk YV, Stakhovskiy OE. Application of nephrometry for choice of the treatment tactics in patients, suffering nephrocellular cancer Klin Khir. 2015 Mar;(3):55-60. [in Ukrainian].

9. Tang T, Jiang H, YuY, He F, Ji SZ, Liu YY, et al. A new method of wound treatment: targeted therapy of skin wounds with reactive oxygen species-responsive nanoparticles containing SDF- $1 \alpha$. Int J Nanomedicine. 2015 Oct 19;10:6571-85. doi: 10.2147/IJN.S88384.

10. Sun M, Lughezzani G, Perrotte P, Karakiewicz PI. Treatment of metastatic renal cell carcinoma. Nat Rev Urol. 2010 Jun;7(6):327-38. doi: 10.1038/nrurol.2010.57 
11. Bindayi A, Hamilton ZA, McDonald ML, Yim K, Millard F, McKay RR, et al. Neoadjuvant therapy for localized and locally advanced renal cell carcinoma. Urol Oncol. 2018 Jan;36(1):31-37. doi: 10.1016/j. urolonc.2017.07.015.

12. Porta C, Paglino C, Grünwald V. Sunitinib re-challenge in advanced renal-cell carcinoma. Br J Cancer. 2014 Sep 9;111(6):1047-53. doi: 10.1038/bjc.2014.214.

13. Powles T, Kayani I, Blank C, Chowdhury S, Horenblas S, Peters J, et al. The safety and efficacy of sunitinib before planned nephrectomy in metastatic clear cell renal cancer. Ann Oncol. 2011 May;22(5):1041-7. doi: 10.1093/annonc/mdq564.

14. Jonasch E, Wood CG, Matin SF, Tu SM, Pagliaro LC, Corn PG, et al. Phase II presurgical feasibility study of bevacizumab in untreated patients with metastatic renal cell carcinoma. J Clin Oncol. 2009 Sep 1;27(25):4076-81. doi: 10.1200/JCO.2008.21.3660.

Отримана 08.11.2018 